\title{
TRAINING NEEDS OF WOMEN VEGETABLE FARMERS IN AKINYELE LOCAL GOV- ERNMENT AREA OF OYO STATE, NIGERIA
}

\author{
OT Yekinni ${ }^{1 *}$ and MI Oguntade ${ }^{2}$ \\ ${ }^{1}$ Department of Agricultural Extension and Rural Development, University of Ibadan, Ibadan, Nigeria \\ ${ }^{2}$ Department of Agricultural Technology, Institute of Agricultural Research \& Training, Apata, Ibadan, Nige- \\ ria
}

\begin{abstract}
The need to strengthen the intellectual capabilities of women in their enterprises is important so as to improve their capacities to contribute to household and national development. Any of such intervention should be based on knowledge of the situation to be meaningful. The study assessed the training needs of women farmers on vegetable productions. The study was carried out in Akinyele local government area of Oyo state, Nigeria. Multistage sampling proce-dure was used to obtain primary data from 120 women farmers cultivating vegetable in the local government area. The data was analysed using descriptive statistics such as frequency and percentages while binomial logit regression model was used to analyse the variables in the hypothesis of the study. The result of the analysis re-vealed that the mean age of the women vegetable farmers was 46.45 years and areas of training needs identified by the women were in the areas of chemical weed control, fertiliser selection/rate/application, compost manure preparation. The result of the binomial logit analysis established that involvement in food crop production signifi-cantly influenced the training needs of women vegetable farmers $(\beta=-0.274, p=0.040)$. The study emphasised the need for the extension agencies to design adequate training programme to meet the needs of women vegetable farmers in the areas of identified training deficiencies.
\end{abstract}

Key words: Women farmers, Training needs, Vegetable production

\section{INTRODUCTION}

Women's role in the economy has often been underestimated, and their work in agriculture has long been invisible. Women now make up the majority of the agricultural sector in developing countries, but recent evidence suggests that their productivity is constrained by lack of appropriate skills training (Collet and Gale, 2009). While policy makers have targeted women population for health and nutrition programmes, they have neglected them as productive agents (FAO, 2005). Adequate recognition of the economic activities of women means that they can be duly targeted in enterprisepromotion programmes so as to improve their standards of living like those of their male counterpart. The thought that women are mostly covered when men are targeted in extension programmes is far from being correct. This is because single women would not have been covered by that strategy apart from the fact that information do not always trickle from the husbands to their wives.

Women face significant barriers in accessing training and education, consequently they have low literacy levels. Domestic obligations, as traditional responsibilities of women usually preclude them from access to trainings though such are even primarily targeted at men. Addressing these challenges to improve women smallholders' access to advanced and relevant training is an important step in increasing agricultural productivity (Collett and Gale, 2009). The importance of the role of women farmers in agricultural production is based on the assumption that their motivation for participation will contribute to household food security. Doss (2011) stated that women account for more than half (between $60 \%$ and $80 \%$ ) of the labour required to produce the food consumed in Africa. Women are particularly vulnerable to environmental changes (Aguilar, 2009) due to

\footnotetext{
*Corresponding author: taofeeq yekinni@yahoo.com
} 
so many factors that confront their situations in developing countries. In the face of changing and increasingly erratic agricultural conditions, there is a huge premium on women's ability to respond innovatively and to be adaptable, in order to ensure food security and the productivity of the agricultural sector in developing countries.

Successful and result-oriented farming requires adequate skills and knowledge from the farmers, which can only be attained through appropriate training. Realisation of need shows that there is lack of something, which if present would make a better situation to individuals or group of individuals. The gap between how job is being performed currently and how it should be performed emphasise the need for training. A situation of need is therefore established when training is required; this can be said to be the difference between what is and what ought to be (Adesoji, 2006).

The significant roles of women in agricultural enterprise activities warrants appropriate education and training, efforts at conducting such programmes especially in rural areas are far from being acceptable (Rousan, 2007). The activities are usually conducted based on the notion of what the implementers thought the beneficiaries needed. The foregoing implies that there must be proper understanding of needs in order to administer successful training exercise. Despite the fact that various researchers (Farinde and Ajayi, 2005; Adeola and Ayoade, 2011; Ayanwuyi and Zaka, 2011; Mech et al, 2010) have been carried out studies on training needs of women farmers in agriculture, this study found it necessary to investigate specifically on vegetable production so as to ascertain their general and peculiar situations as well as the constraints they encounter in terms of access to adequate training in their enterprises. Based on the foregoing, the study was set to achieve these objectives.

The main objective of this study was to assess the training needs of women vegetable farmers in the study area. The specific objectives were to;
1. Identify the socioeconomic characteristics of women vegetable farmers.

2. Highlight the enterprise characteristics of women vegetable farmers.

3. Discern the training needs of the women vegetable farmers.

The study hypothesised that 'there is no significant relationship between the enterprise characteristics of women vegetable farmers and their training needs'.

One of the cogent attempts to improve the contributions of women to household and community development is to meet their training needs, which imply efforts to increase their knowledge and promote their enterprises. Such effort will ultimately translate to improved food production for enhanced household food security and poverty alleviation. The report of this study will be useful to policy makers on agricultural development and poverty alleviation programmes. It will also be relevant to Non-Governmental Organisations (NGOs) whose area of concern is women empowerment.

\section{METHODOLOGY}

The study was carried out in Akinyele local government area of Oyo state in Nigeria, with coordinates between latitude $7^{\circ} 28^{\circ}$ and $7^{\circ} 31^{\circ}$ and longitude $3^{0} 53^{`}$ and $3^{0} 57^{\circ}$. The local government area has its headquarters at Moniya in Ibadan. It has a land area of $414,892 \mathrm{~km}^{2}$. It is located in the rain forest zone and grassland of South Western Nigeria. The area has a tropical climate, which is characterised by two distinct seasons; the raining season and the dry season. The raining season begins in April and last till October while the dry season commences in November and last till March. Farming is the primary occupation of the people in the area and the type of crops cultivated includes maize, yam, cassava and vegetables among others. The local government area is one of the beneficiaries of the Fadama II project because of the preponderance of dry season vegetable production in the area. 
The population of the study comprises women farmers cultivating vegetable in the local government area.

Multistage sampling method was used to select the respondents of the study. The first stage involved a random selection of $50 \%$ of the wards in Akinyele local government, which give six wards. The second stage involved a purposive selection of one village from each of the selected wards on the basis of concentration of women vegetable farmers. Then, quota (equal number) random sampling technique was used to select twenty respondents from each of the villages, thereby making a sample size of 120 respondents.

The instrument used for data collection was structured questionnaire which was administered as interview schedule, using the local dialect in order to circumvent illiteracy barrier among the respondents of the study.

The dependent variable of the study is training needs of the women vegetable farmers. This was measured by making the respondents indicate areas of training needs and the extent to which the training are required. The responses were taken on a three-point scale of not at all (scored 0), much (1) and very much (2). An index of training need was therefore derived from the responses.

The independent variables include the personal characteristics such as age, taken in actual years; marital status, taken from options of single, married, divorced etc; religion, with the options of Islam, Christianity, Traditional and others; education, taken in number of years in formal schools; tribe, with the options of Yoruba, Igbo, Hausa Egun etc. Also measured are enterprise characteristics such as type of vegetable cultivated, other crops cultivated, farm size, source of farmland, source of information, access to extension service and constraints to training.
Collected data were analysed by using descriptive and inferential statistics. The descriptive analytical tools used are percentages and frequencies. Binomial logit regression model was used to test the hypothesis between enterprise characteristics such as farming experience, land tenure, farm size, farming type, source of labour and labour cost; and training need (dependent variable) of the farmers.

\section{RESULTS AND DISCUSSION}

\section{Socioeconomic characteristics of the re- spondents}

The result of analysis of data presented in Table 1 shows that the modal response for ages of the respondents $(40.8 \%)$ fall between 41 and 50 years while mean age is 46.45 years. This implies that the respondents were mostly in their middle ages. Also, most $(76.7 \%)$ of the respondents were married and $(82.5 \%)$ of Yoruba by tribal affiliation.

Result also showed that $47.5 \%$ of the respondents have no formal education and $38.3 \%$ of them have primary education. With a mean of 3.83 years of formal education, it implies that majority of the respondents do not have appreciable formal education. Also, most (78.3\%) of the respondents have vocational education; this implies that majority of the women vegetable farmers have more access to informal education, especially vocational education in the study area.

In terms of occupation, majority (52.5\%) of the respondents are into farming as their primary occupation while $47.5 \%$ of them are engaged in farming as secondary occupation. This implies that farming is the most prevalent income generating activity in the study area. The result also revealed that $80.8 \%$ of the respondents have between 5 and 10 persons in their families, with the mean family size of 8.17 persons. This indicates that the 
respondents have fairly large family sizes in the study area.

Table 1: Distribution of respondents by socioeconomic characteristics

\begin{tabular}{|c|c|c|}
\hline $\begin{array}{l}\text { Socioeconomic character- } \\
\text { istics }\end{array}$ & Frequency & Percentage \\
\hline \multicolumn{3}{|l|}{ Age (years) } \\
\hline Less than 30 & 4 & 3.3 \\
\hline $30-40$ & 34 & 28.4 \\
\hline $41-50$ & 49 & 40.8 \\
\hline $51-60$ & 29 & 24.2 \\
\hline Above 60 & 4 & 3.3 \\
\hline \multicolumn{3}{|l|}{ Marital status } \\
\hline Married & 92 & 76.7 \\
\hline Single & 4 & 3.3 \\
\hline Divorced & 5 & 4.2 \\
\hline Window & 14 & 11.7 \\
\hline Separated & 5 & 4.2 \\
\hline \multicolumn{3}{|l|}{ Religion } \\
\hline Islam & 63 & 52.5 \\
\hline Christianity & 49 & 40.8 \\
\hline Traditional & 8 & 6.7 \\
\hline \multicolumn{3}{|l|}{ Tribe } \\
\hline Yoruba & 99 & 82.5 \\
\hline Igbo & 14 & 11.7 \\
\hline Hausa & 6 & 5.8 \\
\hline \multicolumn{3}{|l|}{ Education Level } \\
\hline No formal education & 57 & 47.5 \\
\hline Primary education & 46 & 38.3 \\
\hline Secondary education & 11 & 9.3 \\
\hline Tertiary education & 6 & 4.9 \\
\hline \multicolumn{3}{|l|}{ Informal Education } \\
\hline Adult education & 8 & 6.7 \\
\hline Vocational education & 94 & 78.3 \\
\hline Both & 18 & 15.0 \\
\hline \multicolumn{3}{|l|}{ Primary Occupation } \\
\hline Farming & 63 & 52.5 \\
\hline Civil service & 13 & 10.8 \\
\hline Trading & 25 & 20.8 \\
\hline Tailoring & 19 & 15.8 \\
\hline \multicolumn{3}{|l|}{ Secondary Occupation } \\
\hline Trading & 25 & 20.8 \\
\hline Tailoring & 15 & 12.5 \\
\hline Hairdressing & 23 & 19.2 \\
\hline Farming & 57 & 47.5 \\
\hline \multicolumn{3}{|l|}{ Family Size } \\
\hline Less than 5 & 11 & 9.2 \\
\hline $5-10$ & 97 & 80.8 \\
\hline $11-15$ & 12 & 10.0 \\
\hline
\end{tabular}

Source: Field survey, 2009

Enterprise characteristics of the respondents

Results presented in Table 2 shows that
$57.5 \%$ of the respondents have farming experience between 10 and 20 years, with the mean years of experience of 15.54 years. This implies that most respondents have appreciable years of experience.

It also reveals that $39.2 \%$ of the respondents have access to farmland through rent/lease, while $30.8 \%$ of them got land through family access. This implies that most of the respondents have access to land through rent/lease, which is a more reliable mean of ownership. This is expected to have significant influence on the extent to which owners can invest on sustainable use of the asset.

In terms of farm size, result of the study showed that $78.3 \%$ of the respondents had between 1 and 2 acres of farmland. This implies that majority of the respondents were small scales farmers. The study also revealed that $82.5 \%$ of the respondents engage in food crop production while $17.5 \%$ are engaged in mixed farming. This indicates that most of the respondents tends to concentrate more on food crop production.

Also, the information source mostly used by the respondents was extension agents $(58.3 \%)$, followed by contact farmers $(24.2 \%)$. This implied that extension agency is the main information source to the women farmers, as the idea of contact farmers is a strategy to reach the women indirectly in order to circumvent cultural barriers that prevent women from interactive with male strangers.

In terms of labour use, the result revealed that $85.8 \%$ of the respondents use hired labour on their farms, implying that most of them use hired labour than family labour in their enterprises.

The study also revealed that $75.0 \%$ of the respondents pay between N500 (\$3.12) and $\mathrm{N} 1000(\$ 6.24)$ to hired labour per day. This is an indication of the proportion of labour cost 
in the total cost of production in the enterprise.

Table 2: Distribution of Respondents by enterprise characteristics

\begin{tabular}{|c|c|c|}
\hline Characteristics & Frequency & Percentage \\
\hline $\begin{array}{l}\text { Farming Experiences } \\
\text { (Years) }\end{array}$ & & \\
\hline Less than 10 & 26 & 21.7 \\
\hline $10-20$ & 69 & 57.5 \\
\hline $21-30$ & 21 & 17.5 \\
\hline $31-40$ & 3 & 2.5 \\
\hline Above 40 & 1 & 0.8 \\
\hline \multicolumn{3}{|l|}{ Source of Land } \\
\hline Inherited & 27 & 22.5 \\
\hline Rented leased & 47 & 39.2 \\
\hline Gift & 9 & 7.5 \\
\hline Family land & 37 & 30.8 \\
\hline \multicolumn{3}{|l|}{ Farm Size } \\
\hline Less than 1 & 2 & 1.7 \\
\hline $1-2$ & 94 & 78.3 \\
\hline $3-4$ & 17 & 14.2 \\
\hline Above 5 & 7 & 5.8 \\
\hline \multicolumn{3}{|l|}{ Farming Type } \\
\hline Food crop production & 99 & 82.5 \\
\hline Mixed farming & 21 & 17.5 \\
\hline \multicolumn{3}{|l|}{ Labour type } \\
\hline Hired & 103 & 85.8 \\
\hline Family & 12 & 10.0 \\
\hline Both & 5 & 4.2 \\
\hline \multicolumn{3}{|l|}{ Information source } \\
\hline Extension agent & 70 & 58.3 \\
\hline Contact farmers & 29 & 24.2 \\
\hline Mass media & 21 & 17.5 \\
\hline \multicolumn{3}{|l|}{ Labour cost per day (N) } \\
\hline Less than 500 & 15 & 12.5 \\
\hline $500-1000$ & 90 & 75.00 \\
\hline Above 1000 & 15 & 12.5 \\
\hline Total & 120 & 100.0 \\
\hline
\end{tabular}

Source: Field Survey, 2009

\section{Training needs of women vegetable farm- ers}

The result presented in Table 3 shows that $67.5 \%$ of the respondents had attended a training programme or the other while only $32.5 \%$ of the respondents have never attended any training programme. This means that most of the vegetable farmers have access to training programmes in the study area. The finding also showed that $30.8 \%$ of the respondents had their training on child care, $9.2 \%$ of them had training in family planning, 50.8\% had training in arts and crafts, $15.0 \%$ had training on adult literacy and $39.2 \%$ had training in farming activities. It is evident from this result that the modal response was training on farming activities, which is expected to have positive impact on their farming enterprises.

Regarding the reasons for not attending some of the training programmes, responses revealed that $61.7 \%$ of the respondents were not aware, husband's of $3.3 \%$ of them did not allow them to attend, $10.0 \%$ claimed that women were not invited, the time was not convenient to $10.0 \%$ of them, venue was too far for $10.8 \%$ of them while $4.2 \%$ of them did not attend training programme because of sickness/infirmity. This showed that lack of awareness of the programmes is the modal item as reason for not attending the training programmes.

Table 3: Distribution of respondents by information on trainings attended

\begin{tabular}{lrr}
\hline $\begin{array}{l}\text { Training need of respon- } \\
\text { dents }\end{array}$ & Frequency & Percentage \\
\hline Training programme at- & & \\
$\begin{array}{l}\text { tendance } \\
\text { Yes }\end{array}$ & 81 & 67.5 \\
No & 39 & 32.5 \\
Focus of training & & \\
Child care & 37 & 30.8 \\
Family planning & 11 & 9.2 \\
Arts and crafts & 7 & 5.8 \\
Adult literacy & 18 & 15.0 \\
Farming & 47 & 39.2 \\
Reasons for not attending & & \\
training & & \\
I was not aware & 71 & 61.7 \\
My husband disallow & 4 & 3.3 \\
Women are not invited & 12 & 10.0 \\
Time was not convenient & 12 & 10.0 \\
Venue was too far & 13 & 10.0 \\
Sickness & 5 & 4.2 \\
Total & $\mathbf{1 2 0}$ & $\mathbf{1 0 0 . 0}$ \\
\hline
\end{tabular}

Source: Field Survey, 2009

\section{Specific training needs}

In terms of specific training needs of the respondents, the results as shown in Table 4 re- 
vealed that the areas in which most of the respondents require training, in order of preferences, are pest and diseases control methods, fertiliser application, fertiliser selection/rate, storage methods and procedure, harvesting time and techniques, nursery operations, planting methods, transplanting operations, chemical weed control and seeding rate among other ones.

Table 4: Distribution of respondents by areas of desired training

\begin{tabular}{|c|c|c|c|c|}
\hline $\begin{array}{l}\text { Areas of de- } \\
\text { sired training }\end{array}$ & $\begin{array}{l}\text { Very } \\
\text { much }\end{array}$ & Much & $\begin{array}{l}\text { Not at } \\
\text { all }\end{array}$ & $\begin{array}{l}\text { Weighted } \\
\text { score }\end{array}$ \\
\hline $\begin{array}{l}\text { Pest/disease } \\
\text { control method }\end{array}$ & $\begin{array}{l}109 \\
(90.8)^{*}\end{array}$ & $11(9.1)$ & $0(0.0)$ & 190.7 \\
\hline $\begin{array}{l}\text { Fertiliser appli- } \\
\text { cation }\end{array}$ & $\begin{array}{l}103 \\
(85.8)\end{array}$ & $15(12.5)$ & $1(1.7)$ & 184.1 \\
\hline $\begin{array}{l}\text { Fertiliser selec- } \\
\text { tion/rate }\end{array}$ & $99(82.5)$ & $18(16.7)$ & $1(1.8)$ & 181.7 \\
\hline $\begin{array}{l}\text { Storage meth- } \\
\text { ods \& proce- } \\
\text { dures }\end{array}$ & $\begin{array}{l}100 \\
(83.3)\end{array}$ & $18(15.0)$ & $2(1.7)$ & 181.6 \\
\hline $\begin{array}{l}\text { Harvesting } \\
\text { time \& tech- } \\
\text { niques }\end{array}$ & $94(78.3)$ & $24(20.0)$ & $2(1.7)$ & 176.6 \\
\hline $\begin{array}{l}\text { Nursery opera- } \\
\text { tions }\end{array}$ & $92(76.7)$ & $27(22.5)$ & $1(0.8)$ & 175.9 \\
\hline $\begin{array}{l}\text { Planting meth- } \\
\text { ods }\end{array}$ & $93(77.5)$ & $23(19.2)$ & $4(3.3)$ & 174.2 \\
\hline $\begin{array}{l}\text { Transplanting } \\
\text { operations }\end{array}$ & $92(76.7)$ & $25(20.8)$ & $3(2.5)$ & 174.2 \\
\hline $\begin{array}{l}\text { Chemical weed } \\
\text { control }\end{array}$ & $91(75.8)$ & $27(22.8)$ & $2(1.7)$ & 174.2 \\
\hline Seeding rate & $93(77.5)$ & $23(19.1)$ & $4(3.3)$ & 174.1 \\
\hline $\begin{array}{l}\text { Compost ma- } \\
\text { nure prepara- } \\
\text { tion }\end{array}$ & $91(75.8)$ & $26(21.7)$ & $3(2.5)$ & 173.3 \\
\hline Seed selection & $89(74.2)$ & $24(20.0)$ & $7(5.8)$ & 168.4 \\
\hline Bed making & $84(70.0)$ & $27(22.5)$ & $9(7.5)$ & 162.5 \\
\hline Bush burning & $69(57.5)$ & $37(30.8)$ & 14 (11.7) & 145.8 \\
\hline Bush clearing & $60(50.0)$ & $52(43.4)$ & $8(6.7)$ & 143.4 \\
\hline
\end{tabular}

Source: Field Survey, 2009

*Multiple responses

The hypothesis sought to test for relationship between enterprise characteristics of the respondents and their training needs. The dependent variable of the study i.e. training need was tested against selected enterprise characteristics of the respondents using binomial logit regression model for the analysis. The result in Table 5 reveals that involvement in food crop production was the only enterprise characteristic that significantly influenced training needs $(\beta=-0.2745 ; p=0.0400)$. This implies that farmers with focus on food crop production do not need as much of training as other farmers with focus on cash crop and mixed farming. This can be explained by the fact that their interaction with food crop enterprises has fulfilled some of their information needs to have required fewer training than others. Other variables such as farming experience, source of land, farm size, labour type and labour cost per day were not significant to the training needs of the women vegetable farmers.

Table 5: Binomial logit regression between training needs and enterprise characteristics

\begin{tabular}{lllll}
\hline $\begin{array}{l}\text { Enterprise } \\
\text { characteris- } \\
\text { tics }\end{array}$ & $\begin{array}{l}\text { Standard- } \\
\text { ised } \\
\text { coefficient }\end{array}$ & $\begin{array}{l}\text { t- } \\
\text { value }\end{array}$ & $\begin{array}{l}\text { p- } \\
\text { value }\end{array}$ & Remark \\
\hline $\begin{array}{l}\text { Farming } \\
\text { experience }\end{array}$ & 0.25396807 & 1.529 & 0.1262 & $\begin{array}{l}\text { Not signifi- } \\
\text { cant }\end{array}$ \\
$\begin{array}{l}\text { Source of } \\
\text { land }\end{array}$ & 0.18952616 & 0.915 & 0.3601 & $\begin{array}{l}\text { Not signifi- } \\
\text { cant }\end{array}$ \\
$\begin{array}{l}\text { Farm size } \\
\text { Food crop }\end{array}$ & -0.18557584 & -1.613 & 0.1068 & $\begin{array}{l}\text { Not signifi- } \\
\text { cant }\end{array}$ \\
$\begin{array}{l}\text { production } \\
\text { Labour type }\end{array}$ & 0.60376531 & -1.673 & 0.0943 & $\begin{array}{l}\text { Not signifi- } \\
\text { cant }\end{array}$ \\
$\begin{array}{l}\text { Labour cost } \\
\text { per day }\end{array}$ & 0.005315182 & 0.402 & 0.6875 & $\begin{array}{l}\text { Not signifi- } \\
\text { cant }\end{array}$ \\
\hline
\end{tabular}

Source: Data analysis computation, 2009

\section{CONCLUSION}

Based on the findings from the study findings, it could be concluded that women vegetable farmers in the study were mostly illiterate, which is expected to be a critical factor affecting training needs. Lack of awareness of programmes as the commonest reason for their inability to attend training programmes, implied that most women were not involved sufficiently in the agricultural training programmes in the study area.

\section{RECOMMENDATIONS}

Based on the finding of the study, the follow- 
ing are recommended:

1. There should be conscious efforts to organise adult education/literacy programme for the women farmers since most of them are not formally educated.

2. The identified training needs of the respondents should be the focus of the extension agencies in the study area.

3. It important to inform women farmers adequately about training programmes, especially those who may not be well covered by the traditional extension information dissemination methods.

\section{REFERENCES}

Adeola RG and Ayoade AR 2011 Extension agents' perception of the information needs of women farmers in Oyo State, Nigeria. Global Journal of Human Social Science. 11 Issue (10) : 32-36.

Adesoji SA, Farinde AJ and Ajayi OA 2006 Assessment of the training needs of Fadama farmers for future agricultural extension work development in Osun State, Nigeria. Journal of Applied Sciences, 6: 3089-3095.

Aguilar L 2009 Training manual on gender and climate change. Global gender and climate alliance. Accessed 21 September 2010. http:// cmsdata.iucn.org/downloads / eng_version_web_final_1.pdf.

Ayanwuyi E and Zaka KO $20 \overline{1} 1$ Analysis of extension service needs of women cassava farmers in Akinyele local government area of Oyo state, Nigeria. Continental J. Agricultural Economics 5 (1): 1 - 6 .

Collett K and C Gale 2009 Training for rural development: Agricultural and Enterprise Skills for Women Smallholders. City and Guilds Centre for Skills Development, West Smithfield, London.

Doss C 2011 'If women hold up half the sky, how much of the world's food do they produce?' ESA Working Paper No. 11
-04. Agricultural Development Economics Division, Food and Agriculture Organization of the United Nations, Rome. Accessed 15 July 2012. http:// www.fao.org/docrep/ 013/am309e/ am309e00.pdf.

FAO 2005 Agricultural extension and training needs of farmers in the small island countries: A case study from Samoa. Research, Extension and Training Division, Sustainable Development Department, FAO, Rome, p 8.

Farind, AJ and Ajayi AO 2005 Training Needs of Women Farmers in Livestock Production: Implications for rural development in Oyo State of Nigeria. Kamla-Raj, J. Soc. Sci., 10(3): 159 $-164$.

Mech D, Handique PK and Barman H 2010 Training needs of rural women in era Culture in Assam province. Global Journal of Human Social Science Vol. 10 Issue 7 (Ver 1.0): 5-8.

Rousan LM 2007 Women farmers and their educational needs in small ruminant production in the Northern Badia region of Jordan. American-Eurasian Journal of Agriculture \& Environ. Sci., 2 (4): 369-374. 